\title{
THE IMPLEMENTATION OF LEGAL POLITICS IN RELATION TO THE GOVERNMENT'S FUNCTION IN DETERMINING WORKER'S WAGES IN THE PERSPECTIVE OF THE PRINCIPLE OF JUSTICE AND THE PRINCIPLE OF LEGAL CERTAINTY
}

\author{
Wiwi Yuhaeni ${ }^{1}$, Sri Dewi Sartika ${ }^{2}$ \\ ${ }^{1}$ Faculty Of Law, Universitas Pasundan, West Java, Indonesia \\ ${ }^{2}$ Universitas Sangga Buana (YPKP), West Java, Indonesia
}

Wiwiyuhaeni226@gmail.com

\begin{abstract}
Wage system need to be developed by taking into account the balance between work performance or productivity, workers needs and company capabilities. The formulations of the problem, how the implementation of the legal politics is related to the functions of government in the application of workers wages in the perspective of the principle of justice and the principle of justice and the principle of legal certainty. Research methods using normative judicial methods and analytical descriptive approaches and analyzed qualitatively. The conclusion is the based on Law Number 13 of 2003 Conrcerning Emploiment, that income that meets a decent income is intended for workers and their families, whereas in The Minister of Labor and Transmigration Regulation Number - PER13/MEN/VII.2012, the need for a decent living is only intended only for workers or single workers.
\end{abstract}

Keywords : Politic of Law, Worker Wages.

\section{Introduction}

Wage is the worker's right that should be able to meet the needs of themselves and their families. Wage systems need to be developed by taking into account the balance between work performance or productivity, workers' needs and the company's ability. In the face of an increasingly developed economic era where everyone's needs are increasing as well. Indonesia as a developing country must at least prepare early efforts to anticipate this era.One effort that must be done is the need for a critical study of the livelihoods of workers / laborers, which is still a matter of employment system in Indonesia, in particular the fulfillment of workers' wages which are still felt to be low. Fulfillment of workers' welfare has actually received the attention of the government, as mandated in the state's outline: "Wages and remuneration policies are based on the necessities of life, developing oneself and family workers in a wage system that does not cause social inequalities by considering achievements and human values that give rise to self-esteem".

The People's Consultative assembly's decree is an implementation of legal politics and the responsibility of the government in providing guarantees for healthy wage conditions so that workers' interests can be protected.Along with Indonesia's unstable economic growth, is one of the factors affecting workers' wages. Because the economic instability will affect the prices of basic necessities for the community and especially for workers to meet their daily needs and their families. Likewise 
for entrepreneurs influence the company's production costs and will also affect the company's survival.In determining the Minimum Wage at the moment must refer to the needs of a decent life, but in its regulation there are very basic differencesaffecting wages in Indonesia, namely in Law Number 13 of 2003 concerning Employment, it is stated that in the definition of decent living needs intended for workers and their families while in the implementing regulations namely Manpower decree No. Per-13 / Men / VII / 2012 concerning Components and Implementation Stages of Achieving the Need for a Decent Life, intended only for single workers without a family.

This is very influential on the amount of wages to be received by each worker and wages that must be issued by employers and will affect the social security of workers or severance pay and others. Now applies PP No.78 of 2015 concerning Wages, wherein in Article 4 paragraph (1), it is stated that an adequate income (needs) for himself as well as for his family. The contents of the article are the same as those contained in Law No. 13 of 2003 concerning Employment, namely the acquisition of wages in addition to himself as well as for his family, which results in injustice and lack of legal certainty for workers / laborers in the territory of Indonesia.

This is a big challenge for the Wage Board in providing advice and consideration for setting minimum wages based on the needs of decent living, because each party related to wages must have the same view in advance to set the minimum wage in order to produce policies based on objective data and careful consideration, so that it will not be a problem in the future.

With the above background, the writer is interested in conducting research with the title: "The Implementation of Legal Politics in Relation to the Government's Function in Determining Worker's Wages in the Perspective of the Principle of Justice and the Principle of Legal Certainty".As the background outlined above, the formulation of the problem is how the Implementation of Legal Politics has to do with the Government's
Function in Determining Workers' Wages in the Perspective of the Principle of Justice and the Principle of Legal Certainty.

\subsection{Political Law and Government}

Functions in Employment.

Labor's Empowerment and utilization is an integrated activity to provide the widest employment opportunities for Indonesian workers. Through this activity Indonesian workers can participate optimally in National Development, but still uphold their human values.These human values include protection of the rights to work relations, protection of basic rights of workers / laborers to negotiate with employers and strikes, protection of occupational safety and health, special protections for women, children and workers disability, protection of wages, welfare, and labor social security (Social security now BPJS Employment) as well as protection of the right to terminate employment.

Work protection is one of the implementations of government legal politics. Legal politics is legal policy that will or has been implemented nationally by the government. In Indonesia, political law is related to the function / task of the labor sector is the government in this case the government in the strict sense of the President (executive) together with the House of Representatives, then the Governor together with the Provincial Regional Representative Council and the Regent or Mayor with District or City Regional Representative Council. The function or task of the government is one of the implementations of welfare for its citizens, especially in employment.

\subsection{Labor Law, Workers, Wages and Decent Livelihoods}

Understanding Employment act, formerly called labor law or in Dutch called arbeidrechts. None of the limits of understanding can be satisfying because each jurist has a different point of view, as a result the understanding he makes is certainly different between one opinion and the other. Opinions of legal experts regarding the definition of labor law include:

1) Molenaar, stated that: 
"Labor Law is part of the applicable law, which basically regulates the relationship between labor and employers, between labor and labor and between labor and the authorities (government)".

2) Mok, mentioned that:

"Labor Law is a law relating to work carried out under the leadership of others with a living condition that is directly coupled with the work".

3) Soepomo, stated that:

"Labor Law is a collection of regulations, both written and unwritten, which relate to incidents where a person works for someone else for a salary."

Abdul Khakim, argued that the term labor contains a very broad understanding and argues that the term labor law is more appropriate than the term labor law. This is also in line with the naming of Law Number 13 Year 2003 concerning Employment, not Labor Law. According to Article 1 point 3, it is stated that: "A worker / laborer is any person who works for a wage or other remuneration".The definition of Wages as stated in article 1 point 30:"Workers' rights are received and expressed in monetary form in return from employers or employers for workers / laborers who are determined and paid according to a work agreement, agreement, or legislation, including benefits for workers / laborers and their families for an work and / or services that have been or will be performed ".In the Elucidation of Article 88 paragraph (1) explained that:

"Income that fulfills a decent livelihood is a reasonable amount of income or income of workers / laborers and their families which includes food, drinks, clothing, housing, education, recreation, and old age insurance".Article 1 paragraph (1) Regulation of the Minister of Manpower and Transmigration No.PER-13 / MEN / VII / 2012 concerning the Components and Implementation of the Stages of Achieving the Need for Decent Living, the definition of decent living needs is explained:
"Standard needs that must be met by a single worker / laborer to be able to live properly both physically, non-physically and socially for the needs of 1 (one) month".According to Government Regulation No.78 of 2015 concerning Wages, where in Article 4 paragraph (1), it is stated that:

"Decent income (needs) is the amount of income or income of workers / laborers from their work results in addition to themselves as well as for their families".

1.3 The Principle of Justice and the Principle of Legal Certainty in Workers' Wages

Wage policy in Indonesia must meet the principles of justice and the principle of legal certainty required for the rule of law.SudiknoMertokusumo and A.Pitlo:"In a state law, there must be guarantees of law enforcement and the achievement of legal objectives and in law enforcement there are three elements which must always receive attention, namely: justice, benefit or effectiveness, and legal certainty".Neither stated by MoctarKusumaatmadja:"The main purpose of the law is order. Compliance with this order, the basic requirements for an organized society. Another legal objective is the achievement of justice. To achieve order requires legal certainty in association between people in society ".

Romli Atmasasmita's Opinion:"The purpose of integrative law is peace in the balance between legal certainty, usefulness and justice (in one breath)".The law must be implemented and enforced. Everyone expects the stipulation of law in the event of a concrete event. That's what legal certainty wants. Legal certainty is a protection against arbitrary actions, which means someone will be able to obtain something that is expected under certain circumstances. The public expects certainty, because with legal certainty the community will be more orderly. The law is tasked with creating legal certainty, with the achievement of another legal objective, namely order. Law enforcement must benefit the community, besides aiming to create justice. According to SatjiptoRahardjo, legal thinking needs to 
return to its basic philosophy, which is law for humans. With this philosophy, humanity becomes the determinant and legal orientation point. The law is in charge of serving humans, not vice versa. Therefore, the law is not an institution that is free from human interests. The quality of law is determined by its ability to serve human welfare. This has led to progressive "ideological" laws: pro-justice laws and pro-people laws.

\section{Method}

This study used a normative juridical method, and a descriptive analytical approach, as well as analyzed qualitatively, by examining the laws that apply in Indonesia through legislation relating to the issue of workers' wages in the perspective of the principle of justice and the principle of legal protection. The data obtained in the form of primary data and secondary data to be analyzed using qualitative juridical methods. In connection with this research using the normative juridical method, the data obtained in the form of data obtained from library research in the form of secondary data, by examining legal materials, namely primary legal materials, binding legal materials in the form of laws and regulations that have related to research conducted, among others, Law Number 13 Year 2003 concerning Employment.

Secondary legal materials are basically used to provide an explanation of primary legal materials, namely theories obtained from legal literature, research results, scientific articles, and websites related to research and tertiary legal materials are legal materials that provide explanations and instructions for legal materials primary and secondary legal materials, usually in the form of dictionaries, encyclopedias and others.

\section{Result and Discussion}

As the problem formulation listed in the problem identification above, the discussion is as follows: How is the Implementation of Legal Politics in Relation to the Government's Function in determining Worker's Wages in the Perspective of the Principle of Justice and the Principle of Legal Certainty.Reviewing from the above description starting from the background, and identifying problems using the normative juridical method, based on Law Number 13 of 2003 on Employment, income that meets a decent living is intended for workers / laborers and their families. Whereas in the Regulation of the Minister of Manpower and Transmigration No.PER-13 / MEN / VII / 2012, the necessities of decent living are only intended for workers / laborers or single status workers.

So according to the Minister of Manpower and Transmigration there is progress because where is a decent life only for workers itself but the reality in practice companies refer to decent living conditions under Law No.13 of 2003. No wonder there is dissatisfaction from workers / laborers for a demonstration because they ask for demands / rights as workers. Now valid Government Regulation No.78 Th 2015 regarding Wages, in this regulation which is said to live properly as well as Law No. 13 of 2003 concerning Labor. So this is not getting any better but is even worse / cause concern for workers / workers throughout Indonesia.

From the description above, if it is related to the principle of justice and the principle of legal certainty, surely the regency / city minimum wage regulation needs to be changed as a legal politics from the government and back to the "decent living" arrangement as regulated in the Minister of Manpower and Transmigration and implemented in practice. As we know, the Indonesian state is a "rule of law", as stated by Sudikno Mertokusumo and A.Pitlo, the purpose of law in law enforcement there are three elements, namely: justice, benefit or usability and legal certainty. According to Mochtar Kusumaatmadja, that the purpose of law in addition to order is justice. RomliAtamasasmita's opinion, that the purpose of integrative law is the existence of peace in the balance between legal certainty, usefulness and justice (in one breath). SatjiptoRahardjo's opinion, in short, the law is in charge of serving humans, the quality of the law is determined by its ability to serve human welfare.

\section{Conclusion}


Journal Sampurasun : Interdisciplinary Studies for Cultural Heritage

Vol. VI, Number 01, June 2020

Based on the provisions of the City / Regency Minimum Wage that refers to the Provincial Minimum Wage, the regulation on "Decent Living" for workers / laborers throughout Indonesia, needs to be changed and should be the same as in the contents of the Minister of Manpower and Transmigration Regulation Number PER-13 / MEN / VII / 2012 concerning Components and Implementation of the Stages of Achieving the Need for Decent Living, it is explained that the necessities of decent living are only intended for workers / laborers or single status workers. While decent living regulated in Government Regulation No. 78 of 2015 concerning Wages, the necessities of decent living in addition to workers are also used for their families as well as those regulated in Law Number 13 of 2003 concerning Employment. So the content of the PP is that there are setbacks rather than improvements, which are contrary to the principle of justice and the principle of legal certainty for the wages of workers / laborers throughout Indonesia.

\section{Refrences}

Abdul Khakim. (2007). Pengantar Ketenagakerjaan Indonesia Berdasarkan
Undang-Undang Nomor13 Tahun 2003

Tentang Ketenagakerjaan. PT Citra Aditya Bakti.

Bernard L.Tanya, dkk. (2010). Teori Hukum, Strategi Tertib Manusia Lintas Ruang dan Generasi. Genta Publising, Yogyakarta.

Kansil, C.S.T. (1989) Pengantar Hukum dan Tata Hukum Indonesia. Balai Pustaka, Jakarta

Mochtar Kusumaatmadja, Fungsi dan Perkembangan Hukum Dalam Pembangunan Nasional. Bina Cipta, Bandung.

Senjun H.Manulang. (1995). Pokok-Pokok Hukum Ketenagakerjaan di Indonesia, Rineka Cipta,Jakarta.

Sudikno Mertokusumo dan A.Pitlo. (1993). Bab-Bab Tentang Penemuan Hukum. Citra Aditya Bakti,Bandung.

Zainal Asikin, dkk. (1993a) Dasar-Dasar Hukum Perburuhan. PT. Raja Grafindo Persada, Jakarta, 1993a. 